\title{
The use of plasmatic and salivary protein fractions for assessing carioactivity in patients with chronic liver disease of alcoholic etiology
}

\author{
Lecturer Daniela G. BALAN ${ }^{1}$, MD, PhD, Univ. Assist. Dan Piperea-SIANU ${ }^{1}$, DDS, PhD Candidate, \\ Univ. Assist. Andra E. Balcangiu-STROESCU ${ }^{1,2}, \mathrm{MD}$, Assoc. Prof. Vanda R. NIMIGEAN ${ }^{3}$, DDS, PhD, \\ Lecturer Alice Piperea-SIANU ${ }^{4}$, Pharmacist, PhD, Lecturer Alexandru G. CROITORU 5 DDS, PhD, \\ Silvia Maria STOICESCU ${ }^{6}, \mathrm{MD}, \mathrm{PhD}$, Conf. Viorica TARMURE ${ }^{7}$ DDS, PhD,
} Asoc. Prof. Dorin IONESCU ${ }^{8}$, MD, PhD, Univ. Assist. Iulia I. STANESCU ${ }^{1}$, DDS, PhD Candidate

${ }^{1}$ Physiology Department, Faculty of Dental Medicine, "Carol Davila" University of Medicine and Pharmacy, Bucharest

${ }^{2}$ Department of Hemodialysis, Emergency University Hospital, Bucharest

${ }^{3}$ Oral Rehabilitation Department, Faculty of Dental Medicine, "Carol Davila" University of Medicine and Pharmacy, Bucharest

${ }^{4}$ Toxicology Department, Faculty of Pharmacy, "Titu Maiorescu" University, Bucharest

${ }^{5}$ Pathophysiology and Immunology Department, Faculty of Dental Medicine,

"Carol Davila" University of Medicine and Pharmacy, Bucharest

${ }^{6}$ Discipline of Obstetrics-Gynecology, "Polizu Hospital”, Faculty of General Medicine,

"Carol Davila" University of Medicine and Pharmacy, Bucharest

${ }^{7}$ Department of Orthodontics and Dento-facial Orthopedics, Faculty of Dentistry,

"Iulia Hateganu" University of Medicine and Pharmacy, Cluj-Napoca

${ }^{8}$ Department of Medical Semiology, Discipline of Internal Medicine I and Nephrology,

Faculty of Medicine, "Carol Davila" University of Medicine and Pharmacy, Bucharest

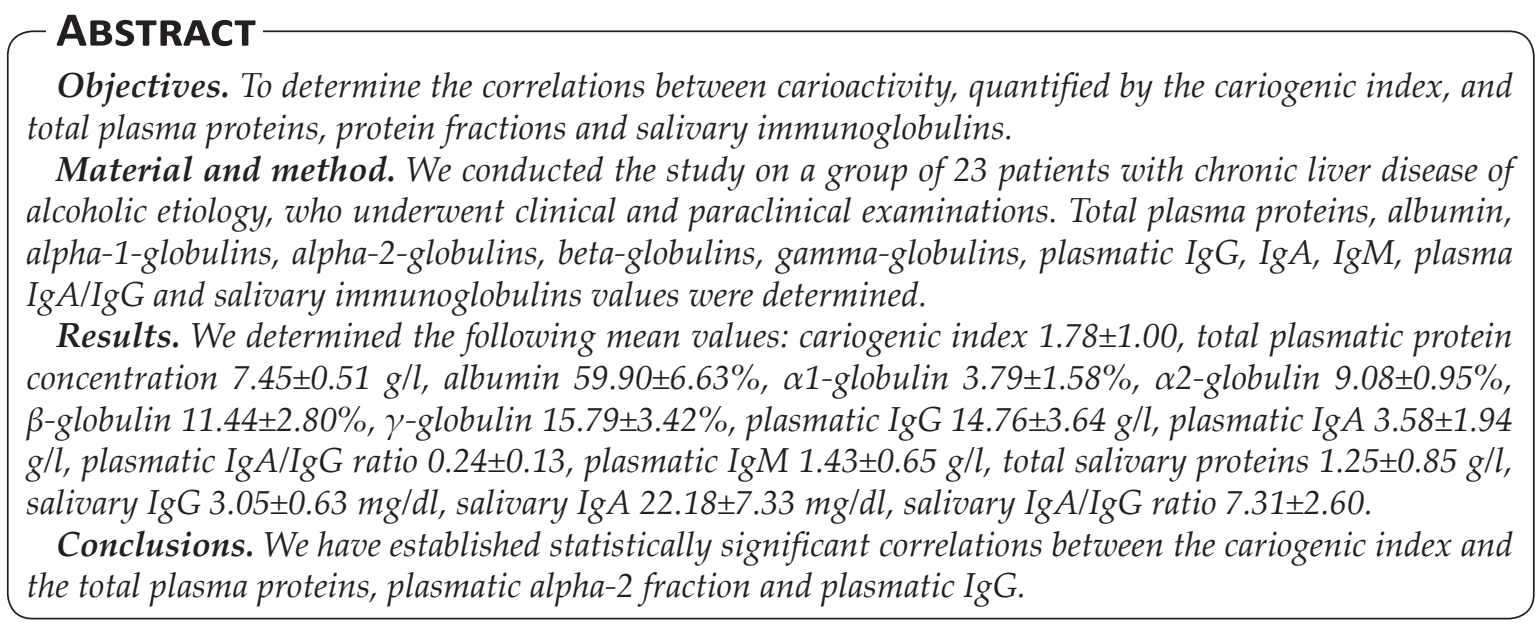

Keywords: enzymes, carioactivity, alcoholic liver disease 


\section{INTRODUCTION}

The consumption of a single concentrated ethanol dose causes a significant reduction in salivary flow. This decrease is associated with impairment concerning the release of total proteins and amylase, as well as electrolytes (1).

The influence of alcohol on saliva and salivary glands consists in damaging the structure and functions of the oral cavity mucosa, the saliva and salivary glands, in other words, in harming both the oral and the general health. In particular, severe tissue damage occurs when alcohol abuse coincides with smoking. Deterioration of oral tissues appears to be primarily due to acetaldehyde, although some acute effects depend on the direct action of ethanol and the formation of reactive oxygen species and esterified ethyl fatty acids (2).

In the European Union, the problem of alcohol addiction affects about $5 \%$ of men and $1 \%$ of women. Pathological changes may occur in all structures of the oral cavity (teeth, periodontium, salivary glands, mucosa, tongue). Individuals with alcohol addiction exhibit a higher percentage of carious lesions and chemical damage to the enamel and dentin as well as periapical impairment (3).

\section{OBJECTIVES}

In the study we conducted, we wanted to investigate the correlations between the frequency of dental caries, quantified through the cariogenic index, and a series of blood and salivary parameters in patients with chronic hepatic impairment of alcoholic etiology.

We analyzed the correlations that occur between the cariogenic index and total plasma proteins and their fractions. Concerning the saliva, we determined the correlations between the cariogenic index and salivary immunoglobulins.

In the light of the results obtained, we have drawn conclusions that may be helpful in understanding how plasma protein analysis or saliva use can be a method of assessing the extent of carious lesions in these patients.

\section{MATERIAL AND METHOD}

We conducted the study on a group of 23 patients with chronic liver disease of alcoholic etiology, who underwent clinical and paraclinical examinations. The study group consisted of 21 males and 2 females, with a mean age of 40.74 \pm 8.14 years.

The patients in the study group were questioned about the frequency of alcohol consumption and about the approximate amount in the previous half year. Patients who had not consumed alcohol in the previous 6 months were not included in the study.

We determined serum $\mathrm{HBs}$ and $\mathrm{HBe}$ antigens, anti-HBe, anti-HBc, anti-HCV, IgM anti-VHA and anti-HBc antibodies to exclude the viral etiology of hepatic impairment.

Patients with chronic hepatic impairment in the study group had a history of chronic ethanol consumption, negative viral markers, clinical symptomatology and paraclinical results suggestive for hepatic impairment.

Samples of blood and saliva were taken in the morning between 8:30-9:30. Prior to harvesting, the patients went through a 12 -hour fasted state.

Individuals in the study group were not allowed to administer drugs 24 hours prior to harvesting, apart from patients receiving mandatory medication.

Considering the microtrauma that may occur during dental brushing, which can cause plasma exudation and, therefore, may alter the composition of the saliva, dental brushing was performed at least 2 hours prior to saliva harvesting. One hour prior to harvesting, the oral cavity was rinsed with distilled water.

We examined the oral cavity by assessing the status of dental and soft tissue structures. The cariogenic index was used to quantify the missing teeth, as well as treated or untreated coronary and root carious lesions.

\section{RESULTS AND DISCUSSIONS}

The mean values determined for plasma proteins and their fractions are: total protein concentration $7.45 \pm 0.51 \mathrm{~g} / \mathrm{l}$, albumin $59.90 \pm 6.63 \%$, a1-globulin $3.79 \pm 1.58 \%$, $\alpha 2$-globulin $9.08 \pm$ $0.95 \%, \beta$-globulin $11.44 \pm 2.80 \%$, $\gamma$-globulin 15.79 $\pm 3.42 \%$.

Table 1 presents the values of $p$, which represent the statistical significance of the correlation between the cariogenic index and the total plasma proteins, respectively the protein fractions. We have not determined statistically significant correlations between the cariogenic index and the albumin ratio in total protein concentration $(p=-0.417)$, $\alpha 1$-globulins $(p=0.171)$, $\beta$-globulins ( $p=0.394)$ or $\gamma$-globulins $(p=0.382)$. 
TABLE 1. Statistical significance of the correlation between the cariogenic index and the plasma concentrations of total proteins and protein fractions

\begin{tabular}{|l|c|c|c|c|c|c|}
\hline & Total proteins g/dl & Albumin \% & Alpha 1\% & Alpha 2\% & Beta\% & Gamma \% \\
\hline mean value & 7.45 & 59.90 & 3.79 & 9.08 & 11.44 & 15.79 \\
\hline standard deviation & 0.51 & 6.63 & 1.58 & 0.95 & 2.80 & 3.42 \\
\hline correlation with cariogenic index & 0.019 & -0.417 & 0.171 & 0.008 & 0.394 & 0.382 \\
\hline
\end{tabular}

We obtained a highly significant statistical correlation $(p<0.01)$ between the cariogenic index and plasma $\alpha 2$-globulins $(p=0.008)$ and between the cariogenic index and the total protein concentration ( $p=0.019$ ) (Fig. 1). This fraction of plasma proteins is mainly represented by haptoglobin and $\alpha 2$-macroglobulin. Both are considered "acute phase proteins", and can be nonspecifically increased in both acute and chronic inflammatory syndromes. Also, other $\alpha 2$-globulins are: $\alpha$-macroglobulin, ceruloplasmin, $\alpha 2$-antiplasmin, protein $\mathrm{C}, \alpha 2$-lipoprotein.
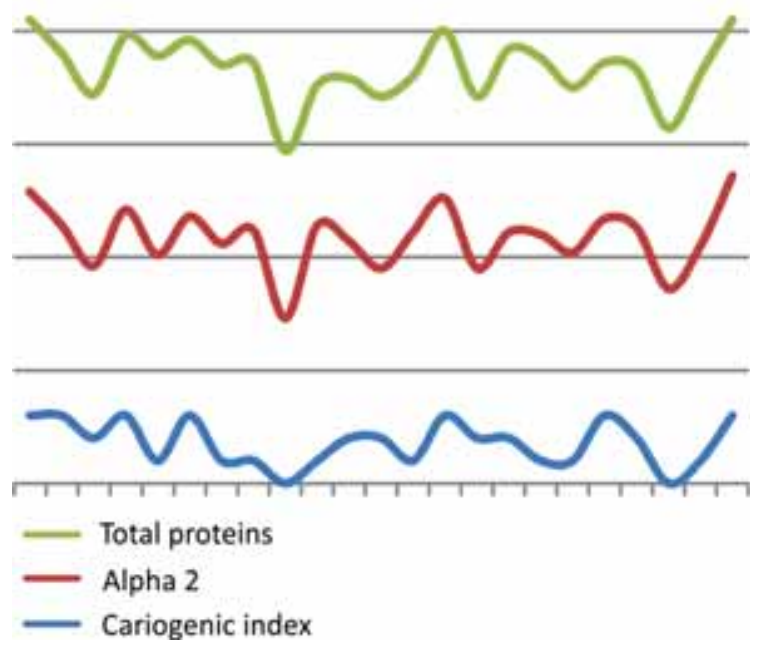

FIGURE 1. The cariogenic index correlates statistically significant with serum total proteins and the alpha-2 fraction of plasma globulins

Regarding the plasma concentrations of total proteins and protein fractions in patients with alcoholic hepatitis, the literature does not mention significant changes in comparison to the physiological values. Thus, even in the case of hepatic cirrhosis, a normal gamma-globulin concentration can be encountered and should be regarded as a positive prognostic element. Also, alcohol consumption without an inflammatory liver component does not cause changes in total albumin or protein. In these patients, an increase in plasmatic albumin concentration is mentioned, possibly due to acetaldehyde resulting from the metabolism of ethylic alcohol.
Other studies mention the decrease in albumin corresponding to the stage of hepatic impairment (chronic alcoholic hepatitis, alcoholic cirrhosis) (4-6).

The mean values determined for the immunoglobulins in the plasma are: immunoglobulin G $14.76 \pm 3.64 \mathrm{~g} / \mathrm{l}$, immunoglobulin A $3.58 \pm$ $1.94 \mathrm{~g} / \mathrm{l}, \mathrm{IgA} / \mathrm{IgG}$ ratio $0.24 \pm 0.13$, immunoglobulin M $1.43 \pm 0.65 \mathrm{~g} / \mathrm{l}$.

Table II shows the values of $p$, which represent the statistical significance of the correlation between the cariogenic index and the serum immunoglobulins mentioned in the previous paragraph.

We have not determined statistically significant correlations between cariogenic index and serum immunoglobulin $A$ concentration $(p=$ $0.402)$, immunoglobulin $M$ concentration ( $p=$ 0.508 ) or IgA/IgG ratio $(p=0.406)$.

TABLE 2. The statistical significance of the correlation between the cariogenic index and the immunoglobulin $G$, immunoglobulin $A, \lg A / \lg G$ ratio, and immunoglobulin $M$

\begin{tabular}{|l|c|c|c|c|}
\hline & IgG g/I & IgA g/I & $\begin{array}{c}\text { Plasmatic } \\
\text { IgA/IgG } \\
\text { ratio }\end{array}$ & IgM g/I \\
\hline mean value & 14.76 & 3.58 & 0.24 & 1.43 \\
\hline $\begin{array}{l}\text { standard } \\
\text { deviation }\end{array}$ & 3.64 & 1.94 & 0.13 & 0.65 \\
\hline $\begin{array}{l}\text { correlation with } \\
\text { cariogenic index }\end{array}$ & 0.006 & 0.402 & 0.406 & 0.508 \\
\hline
\end{tabular}

Highly significant statistical correlations $(p<0.01)$ were obtained between the cariogenic index and serum immunoglobulin $G(p=0.006)$ (Fig. 2).

In patients with chronic alcoholic hepatitis the serum immunoglobulin concentration does not differ significantly from normal. Growth trends of serum IgA and IgG are only reported in alcoholic patients with liver fibrosis component (7).

The correlation between serum IgG and the cariogenic index obtained in our study concurs with the results of Kirtaniya BC et al., who mention a statistically significant correlation between IgG and the number of carious lesions. However, they also mention a correlation be- 
tween IgA and the number of carious lesions, which we did not determine as statistically significant in our study (8).
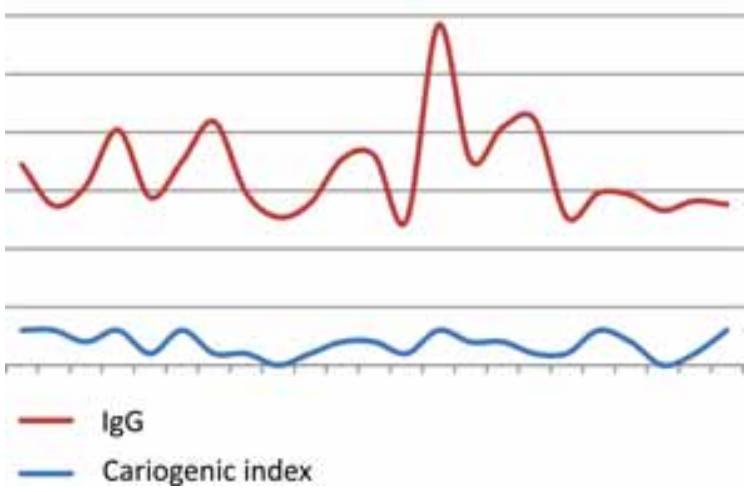

FIGURE 2. The cariogenic index correlates statistically significant with the serum IgG concentration

The mean values for salivary proteins and their fractions are: salivary total protein $1.25 \pm$ $0.85 \mathrm{~g} / \mathrm{l}$, salivary IgG $3.05 \pm 0.63 \mathrm{mg} / \mathrm{dl}$, salivary $\operatorname{lgA} 22.18 \pm 7.33 \mathrm{mg} / \mathrm{dl}$, salivary $\operatorname{lgA} / \operatorname{lgg} 7.31 \pm$ 2.60 .

Table 3 shows the values of $p$, which represent the statistical significance of the correlation between the cariogenic index and the aforementioned salivary parameters. We did not determine statistically significant correlations between the cariogenic index and total protein $(p=-0.105)$, salivary IgG $(p=-0.141)$, salivary $\operatorname{lgA}(p=0.297)$, salivary $\lg A / \lg$ ratio $(p=0.345)$.

TABLE 3. The statistical significance of the correlation between the cariogenic index and the salivary concentrations of total proteins, $\lg G \lg A$ and the $\lg A / \lg G$ ratio

\begin{tabular}{|l|c|c|c|c|}
\hline & $\begin{array}{c}\text { Total } \\
\text { salivary } \\
\text { proteins g/l }\end{array}$ & $\begin{array}{c}\text { Salivary } \\
\text { IgG } \\
\text { mg/dl }\end{array}$ & $\begin{array}{c}\text { Salivary } \\
\text { IgA } \\
\text { mg/dl }\end{array}$ & $\begin{array}{c}\text { Salivary } \\
\text { IgA/IgG } \\
\text { ratio }\end{array}$ \\
\hline mean value & 1.25 & 3.05 & 22.18 & 7.31 \\
\hline $\begin{array}{l}\text { standard } \\
\text { deviation }\end{array}$ & 0.85 & 0.63 & 7.33 & 2.60 \\
\hline $\begin{array}{l}\text { correlation } \\
\text { with } \\
\text { cariogenic } \\
\text { index }\end{array}$ & -0.105 & -0.141 & 0.297 & 0.345 \\
\hline
\end{tabular}

Damle SG et al., in a study on 150 children aged 12 to 15 years, reported statistically signif- icant correlations between the study group (dental caries) and the control group for salivary IgA $(8.50 \pm 1.43 \mathrm{mg} / \mathrm{dl}, 10.63 \pm 2.85 \mathrm{mg} / \mathrm{dl}$, $\mathrm{p}=0.015)$ and total salivary proteins $(3.28 \pm$ $0.12 \mathrm{mg} / \mathrm{dl}, 2.89 \pm 0.11 \mathrm{mg} / \mathrm{dl}, \mathrm{p}=0.015)$. They also mention the lack of correlation between dental caries and salivary IgG concentration $(0.87 \pm 0.14 \mathrm{mg} / \mathrm{dl}, 1.04 \pm 0.31 \mathrm{mg} / \mathrm{dl}, \mathrm{p}=0.085)$. This lack of correlation, which we have also determined in our study, is probably explained by the fact that immunoglobulin $\mathrm{G}$ does not appear to have an anticariogenic role (9-11).

\section{CONCLUSIONS}

Excessive alcohol consumption, especially refined alcohol in the form of concentrated beverages, is a public health problem in Romania and globally, both in terms of prevalence, morbidity and mortality.

Oral changes in patients with chronic hepatic impairment of alcoholic etiology have to be a known element for the dentist. They may be of high interest for the clinician, by affecting both dental and soft parts.

The routine determination of certain plasma parameters, such as total plasma proteins, as well as others, such as immunoglobulin $\mathrm{G}$ and the $\alpha$-2-globulin fraction can help the dentist in assessing the carioactivity. A better understanding of the oral repercussions generated by the systemic context facilitates the correct choice of the oral rehabilitation plan, which is essential for the success of the dental treatment.

\section{Acknowledgment}

Lecturer Daniela G. Bălan, MD, PhD, Univ. Assist. Dan Piperea-Șianu, DDS, PhD Candidate, Univ. Assist. Andra E. Balcangiu-Stroescu, MD, Assoc. Prof. Vanda R. Nimigean, DDS, PhD, Lecturer Alice Piperea-Șianu, Pharmacist, PhD, Lecturer Alexandru G. Croitoru DDS, PhD, Stoicescu Silvia Maria, MD, PhD, Conf. Țărmure Viorica, DDS, PhD, Asoc. Prof. Dorin lonescu, MD, PhD, Univ. Assist. Iulia I. Stănescu, DDS, PhD Candidate share first authorship. 


\section{REFERNCES}

1. de Almeida P. del V., Grégio A.M., Machado M.A. et.al. Saliva composition and functions: A comprehensive review. J Contemp Dent Pract. 2008 Mar 1; 9(3):72-80

2. Waszkiewicz N., Zalewska A., Szulc A. et al. The influence of alcohol on the oral cavity, salivary glands and saliva. $P o l$ Merkur Lekarski. 2011 Jan; 30(175) 69-74.

3. Surtel A., Klepacz R., WysokińskaMiszczuk J. Alcohol dependence syndrome - symptoms in the oral cavity. Postepy Hig Med Dosw (Online). 2014 Jun;68 828-833.

4. Cristani A., Cioni G., Tincani E. Normal gammaglobulin levels in liver cirrhosis: A prognostic indicator and improved survival. Recenti Prog Med. 1991 Jan; 82(1):9-12
5. Tyulina O.V., Prokopieva V.D., Boldyrev A.A. Erythrocyte and plasma protein modification in alcoholism: a possible role of acetaldehyde. Biochim Biophys Acta. 2006 May; 1762(5):558-63

6. Brodie M.J., Boobis S. The effects of chronic alcohol ingestion and alcoholic liver disease on binding of drugs to serum proteins. European Journal of Clinical Pharmacology. November 1978, Volume 13, Issue 6, pp 435-438.

7. Martin D.M., Vroon D.H., Nasrallah S.M. Value of serum immunoglobulins in the diagnosis of liver disease. Liver. 1984 Jun; 4(3):214-8

8. Kirtaniya B.C., Chawla H.S., Tiwari A. et al. Natural prevalence of antibody titers to glucosyltransferase of Streptococcus mutans in serum in high and low caries active children. J Indian Soc Pedod Prev Dent. 2010. 28: 91-94.

9. Damle S.G., Vidya I., Yadav R. et.al. Quantitative determination of inorganic constituents in saliva and their relationship with dental caries experience in children. Dentistry. 2012. 2:131.

10. Lehner T., Clarry E.D., Cardwell J.E. Immunoglobulins in saliva and serum in dental caries. 1967. Lancet 1: 1294-1296.

11. Everhart D.L., Grigsby W.R.,

Carter W.H. Jr. Human dental caries experience related to age, sex, race and certain salivary properties. 1973. J Dent Res. 52: 242- 247. 